\title{
PENYALAHGUNAAN ASET NEGARA TERHADAP PEJABAT SECARA PRIBADI DI LUAR FUNGSI KEDINASAN DAN JABATAN
}

\author{
Cindy Oeliga Yensi Afita \\ Dosen pada Fakultas Hukum Universitas Muara Bungo \\ Jl. Diponegoro No. 27 Kelurahan Cadika, Kecamatan Rimbo Tengah, \\ Kabupaten Bungo Telp/Fax (0747) 323310 Kode Pos 37214 \\ Chinyoeliga@gmail.com
}

\begin{abstract}
RINGKASAN
Penulisan ini bertujuan untuk mengetahui bagaimana bentuk sanksi yang diterapkan bagi pejabat yang menggunakan aset negara di luar fungsi jabatan dan kedinasan serta bagaimana dengan kerugian negara yang ditimbulkan akibatnya. Penulisan ini menggunakan Metode penelitian hukum normatif (normative legal research) yaitu suatu penelitian yang mengkaji baik ketentuan-ketentuan hukum positif maupun asas-asas hukum, dengan melakukan penjelasan secara sistematis hubungan antar ketentuan hukum, hukum dalam hal ini bukan sekedar peraturan perundang-undangan, melainkan juga yurisprudence (case law), nilai-nilai hukum yang hidup dan berkembang di dalam hidup bermasyarakat, asas-asas hukum, dan juga literature hukum yang berisi pandangan para sarjana hukum yang mempunyai kualifikasi yang tinggi (the most highty qualified scholar's opinion). Hasil penulisan ini menunjukkan bahwa Pengelolaan barang milik daerah meliputi: Perencanaan kebutuhan dan penganggaran, Pengadaan, Penerimaan dan penyaluran, Penggunaan, Pemanfaatan, Pengamanan dan pemeliharaan, Penilaian, Penghapusan, Pemindatanganan, Penatausahaan, Pembinaan, pengawasan dan pengendalian, pembiayaan dan tuntutan ganti rugi. Bentuk sanksi yang diberikan bagi pejabat atas kelalaian, penyalagunaan atas pengelolaan barang milik negara/daerah diselesaikan melalui tuntutan ganti rugi sesuai dengan peraturan perundang-undangan yang berlaku. Berdasarkan Undang-Undang Nomor 31 Tahun 1999 Tentang Tindak Pidana Korupsi: Setiap orang yang dengan tujuan menguntungkan diri sendiri atau orang lain atau suatu korporasi, menyalahgunakan kewenangan, kesempatan atau sarana yang ada padanya karena jabatan atau kedudukan yang dapat merugikan keuangan negara atau perekonomian negara, dipidana dengan pidana penjara seumur hidup atau pidana penjara paling singkat 1 (satu) tahun dan paling lama 20 (dua puluh) tahun dan atau denda paling sedikit Rp. 50.000.000,00 (lima puluh juta rupiah) dan paling banyak Rp. 1.000.000.000,00 (satu milyar rupiah).
\end{abstract}

\section{Kata Kunci : Penyalahgunaan Aset Negara, Larangan, Sanksi}

\section{PENDAHULUAN}

\section{Latar Belakang}

Bukan hal yang aneh, jika
penggunaan kendaraan dinas
operasional pelat merah sering
dipergunakan bukan dalam jam kerja
dan untuk kepentingan dinas, bahkan hal
tersebut dapat terlihat di tempat-tempat
wisata juga tempat perbelanjaan.
$\begin{aligned} & \text { Kelancaraan penyelenggaraan } \\ & \text { pemerintahandan pelaksanaan }\end{aligned}$

pembangunan nasional terutama tergantung dari kesempurnaan aparatur negara dan pada pokoknya tergantung dari kesempurnaan Pegawai Negeri Sipil (PNS).

Kedudukan Pegawai Negeri Sipil dalam setiap organisasi pemerintahan mempunyai peranan yang sangat penting, sebab pegawai negeri merupakan tulang punggung pemerintah dalam melaksanakan pembangunan 
nasional. ${ }^{1}$ Adanya Pegawai Negeri Sipil (PNS) sebagai unsur aparatur negara, abdi negara, dan abdi masyarakat yang penuh kesetiaan dan ketaatan kepada Pancasila, Undang-Undang Dasar Tahun 1945, Negara, dan Pemerintah serta yang bersatu padu, bermental baik, berwibawa, berdaya guna, berhasil guna, bersih, bermutu tinggi, dan sadar akan tanggung jawabnya untuk menyelenggarakan tugas pemerintahan dan pembangunan.

Untuk membina Pegawai Negeri Sipil (PNS) yang demikian itu, antara lain diperlukan adanya peraturan disiplin yang memuat pokok-pokok kewajiban, larangan, dan sanksi apabila kewajiban tidak ditaati, atau larangan dilanggar. Namun, masih banyak pejabat maupun Pegawai Negeri Sipil (PNS) yang menggunakan kendaraan dinas tidak pada tempatnya. Mereka tidak memisahkan kendaraan dinas untuk kegiatan dinas dan untuk kegiatan pribadi. Pejabat yang menggunakan kendaraan dinas untuk keperluan pribadi disebabkan rendahnya kesadaran hukum, lemahnya pengawasan dari SKPD terkait, dan belum adanya aturan jelas yang mengatur penggunaan kendaraan dinas pada jam-jam kerja. Kondisi ini menjadi contoh yang buruk yang dapat menjatuhkan kepercayaan masyarakat terhadap integritas moral penyelenggara negara. Pegawai Negeri Sipil (PNS) tidak mengizinkan kendaraan dinas yang melekat setiap Satuan Kerja Perangkat Daerah (SKPD) digunakan untuk keperluan mudik lebaran oleh pejabat maupun pegawai. Larangan penggunaan pelat merah untuk kepentingan mudik lebaran, merupakan ketentuan yang terus diterapkan Pemerintah jika ada pejabat yang ketahuan tetap menggunakan kendaraan dipastikan

1 Nirmala Sari, "Pengangkatan Pegawai Negeri Sipil Dalam Jabatan Struktural, Rio Law

Jurnal, Vol. 1, No. 1, 2020. terkena sanksi sesuai Peraturan Pemerintah Nomor 53 Tahun 2010 Tentang Disiplin Pegawai Negeri Sipil.4 Dalam Peraturan Menteri Dalam Negeri Nomor 19 Tahun 2016 Tentang Pedoman Pengelolaan Barang Milik Daerah Pasal 12 Ayat (3) huruf (d) menyatakan bahwa "Menggunakan barang milik daerah yang berada dalam penguasaannya untuk kepentingan penyelenggaraan tugas dan fungsi SKPD yang dipimpinnya", serta huruf (e) berbunyi "Mengamankan dan memelihara barang milik daerah yang berada dalam penguasaannya". Oleh karena itu, akan lebih baik jika kita mampu segera mengembalikan konsepsi kendaraan dinas sebagai fasilitas atau alat bantu para penyelenggara negara untuk meningkatkan kualitas penyelenggaraan pelayanan kepemerintahan kepada masyarakat. Penyalahgunaan atau ketidaktepatan pemanfaatan kendaraan dinas operasional milik negara yang dibiayai oleh rakyat, akan menciderai perasaan rakyat (comon sense).

Visi Pembangunan hukum di Indonesia mewujudkan negara hukum yang adil dan demokratis melalui pembangunan sistem hukum nasional yang mengabdi pada kepentingan rakyat dan bangsa dalam bingkai Negara Kesatuan Republik Indonesia untuk melindungi segenap rakyat dan bangsa, serta tumpah darah Indonesia, memajukan kesejahteraan umum, mencerdaskan kehidupan bangsa dan ikut melaksanakan ketertiban dunia yang berdasarkan kemerdekaan, perdamaian abadi dan keadilan sosial berdasarkan Pancasila dan UndangUndang Dasar Negara Republik Indonesia Tahun 1945 ( selanjutnya ditulis UUD NRI 1945)

Berdasarkan dengan hal tersebut, Pasal 23 UUD NRI 1945 dalam Perubahan Ketiga menyatakan sebagai berikut: 1. Anggaran Pendapatan dan Belanja Negara sebagai wujud dari pengelolaan keuangan negara ditetapkan setiap tahun dengan Undang-Undang dan 
dilaksanakan secara terbuka dan bertanggung jawab untuk sebesarbesarnya kemakmuran rakyat. 2 . Rancangan Undang-Undang Anggaran Pendapatan dan Belanja Negara diajukan oleh Presiden untuk dibahas bersama Dewan Perwakilan Rakyat dengan memperhatikan pertimbangan Dewan Perwakilan Daerah 3. Apabila dewan Perwakilan Rakyat tidak menyetujuai rancangan anggaran pendapatan dan belanja negara yang diusulkan oleh Presiden, pemerintah menjalankan anggaran pendapatan dan belanja negara tahun yang lalu. Pasal 1 Undang- Undang Nomor 17 Tahun 2003 tentang Keuangan Negara menyatakan bahwa Keuangan Negara adalah semua hak dan kewajiban negara yang dapat dinilai dengan uang, serta segala sesuatu baik berupa uang maupun berupa barang yang dapat dijadikan milik negara berhubung dengan pelaksanaan hak dan kewajiban tersebut. Menurut Indonesian Coruption Watch (ICW) Keuangan Negara berarti semua hak dan kewajiban yang dinilai dengan uang dan segala sesuatu yang dapat dinilai dengan uang maupun berupa barang yang dapat dijadikan milik negara berhubungan dengan pelaksanaan hak dan kewajiban tersebut.1 Berdasarkan Undang-Undang Nomor 1 Tahun 2004 tentang Perbendaharaan Negara, pada Pasal 1 menyatakan bahwa Barang Milik Negara adalah semua barang yang dibeli atau diperoleh atas beban Anggaran Pendapatan dan Belanja Negara atau berasal dari perolehan lainnya yang sah. Peraturan Pemerintah Nomor 6 Tahun 2006 sebagaimana telah diubah dengan Peraturan Pemerintah Nomor 38 Tahun 2008 tentang Pengelolaan Barang Milik Negara/Daerah, mengatur tentang pengelolaan barang milik negara yang meliputi perencanaan kebutuhan dan penganggaran, pengadaan, penggunaan, pemanfaatan, pengamanan dan pemeliharaan, penilaian, penghapusan, pemindahtanganan, penatausahaan, pembinaan, pengawasan, dan pengendalian. Pasal 2 Peraturan
Pemerintah Nomor 38 Tahun 2008 tentang Pengelolaan Barang Milik Negara/Daerah menyatakan bahwa:

(1) Barang milik negara/daerah meliputi: a. Barang yang dibeli atau diperoleh atas beban APBN/APBD; atau b. Barang yang berasal dari perolehan lainnya yang sah.

(2) Barang sebagaimana dimaksud pada ayat (1) huruf b meliputi: a. Barang yang diperoleh dari hibah/sumbangan atau yang sejenis; b. Barang yang diperoleh sebagai pelaksanaan dari perjanjian/kontrak; c. Barang yang diperoleh sesuai dengan ketentuan peraturan perundangundangan; atau $d$. Barang yang diperoleh berdasarkan putusan pengadilan yang telah memperoleh kekuatan hukum tetap. Pasal 3 Ayat (1) Peraturan Pemerintah Nomor 38 Tahun 2008 tentang Pengelolaan Barang Milik Negara/Daerah yang menyatakan bahwa Pengelolaan Barang Milik Negara/Daerah dilaksanakan dengan memperhatikan asas-asas sebagai berikut : a. Asas Fungsional, yaitu pengambilan keputusan dan pemecahaan masalahmasalah di bidang pengelolaan barang milik negara/daerah yang dilaksanakan oleh kuasa pengguna barang, pengguna barang, pengelola barang dan gubernur/bupati/walikota sesuai fungsi, wewenang, dan tanggung jawab masingmasing. b. Asas Kepastian Hukum, yaitu pengelolaan barang milik negara/daerah harus dilaksanakan berdasarkan hukum dan Peraturan Perundang-Undangan. c. Asas Transparansi dan keterbukaan, yaitu penyelenggaraan pengelolaan barang milik negara/daerah harus transparan terhadap masyarakat dalam memperoleh informasi yang benar. d. Asas Efisiensi, yaitu pengelolaan barang milik negara/daerah diarahkan agar barang milik negara/daerah digunakan sesuai dengan batasan-batasan standar kebutuhan yang diperlukan dalam rangka menunjang penyelenggaraan tugas pokok dan fungsi pemerintahan 
secara obtimal. e. Asas Akuntabilitas, yaitu setiap kegiatan pengelolaan barang milik negara/daerah harus dapat dipertanggungjawabkan kepada rakyat. f. Asas Kepastian Nilai, yaitu pengelolaan barang milik negara/daerah harus didukung oleh adanya ketepatan jumlah dan nilai barang dalam rangka obtimalisasi pemanfaatan dan pemindatanganan barang milik negara/daerah serta penyusunan neraca pemerintah. Tetapi pada kenyataannya sekarang banyak aset negara digunakan untuk kepentinggan pribadi. Salah satu kasus penggunaan mobil dinas untuk pulang kampung atau mudik lebaran. Pasal 35 ayat (3) Peraturan Pemerintah Nomor 38 Tahun 2008 tentang Pengelolaan Barang Milik Negara/Daerah, menyatakan bahwa Biaya Pemeliharaan Barang Milik Negara/Daerah dibebankan pada Anggaran Pendapatan dan Belanja Negara/Daerah. Sangat tidak adil ketika negara harus mengeluarkan biaya pemeliharaan dan perawatan akibat penggunaan aset negara secara pribadi di luar fungsi jabatan dan kedinasan seperti memakai mobil dinas untuk pulang kampung saat lebaran atau hari-hari besar lainnya dan untuk keperluan pribadi lainnya. Perbuatan seperti itu diduga dapat merugikan keuangan negara dan secara hukum dapat digolongkan kepada tindak pidana korupsi.

Tindak pidana korupsi merupakan perbuatan yang bukan saja dapat merugikan keuangan negara akan tetapi juga dapat menimbulkan kerugian pada perekonomian rakyat. Barda Nawawi Arief berpendapat bahwa, tindak pidana korupsi merupakan perbuatan yang sangat tercela, terkutuk dan sangat dibenci oleh sebagian besar masyarakat, tidak hanya oleh masyarakat dan bangsa
Indonesia tetapi oleh masyarakat bangsa-bangsa didunia ${ }^{2}$

\section{Rumusan Masalah}

Berdasarkan uraian latar belakang yang disebutkan di atas, maka dapat ditarik suatu masalah. Bagaimana sanksi terhadap pejabat yang melakukan penyalahgunaan kendaraan dinas di luar kegiatan dinas?

\section{IPEMBAHASAN}

\section{Pengertian Aset Negara}

Secara sederhana aset adalah segala harta/kekayaan yang kita miliki, baik harta tersebut memiliki wujud (tangible) maupun tidak memiliki wujud (intangeble), dalam bahasa akuntansi, aset adalah seluruh pengorbanan ekonomis (economic sacrifices) yang dilakukan oleh suatu entitas untuk memperoleh manfaat (benefit) dimasa depan. Pada dunia usaha, aset digunakan secara langsung ataupun tidak langsung untuk memperoleh pendapatan (revenue) perusahaan. Menurut Siregar pengertian aset secara umum adalah barang (thing) atau sesuatu barang (anything) yang mempunyai nilai ekonomi (economic value), nilai komersil (commercial value) atau nilai tukar (exchange value) yang dimiliki oleh badan usaha, instansi atau individu. Sedangkan pengertian aset negara menurut Siregar adalah bagian dari kekayaan negara atau harta kekayaan negara (HKN) yang terdiri dari barang bergerak atau barang tidak bergerak yang dimiliki, dikuasai oleh Instansi Pemerintah, yang sebagian atau seluruhnya dibeli atas beban Anggaran Pendapatan dan Belanja Negara (APBN) serta dari perolehan yang sah, tidak termasuk kekayaan negara yang dipisahkan (dikelola BUMN) dan

2 Khaidir, Analisis Yuridis Pembalikan Beban Pembuktian Pada Tindak Pidana Korupsi", Rio Law Jurnal, Vol. 1, No. 1, 2020. 
kekayaan Pemerintah Daerah. Aset lancar (current asset) merupakan aset yang umumnya digunakan untuk menunjang perolehan pendapatan perusahaan secara langsung.

Aset jenis ini biasanya dipandang memiliki masa manfaat kurang dari 12 bulan. Sedangkan aset tidak lancar (non current asset) adalah jenis aset yang diperoleh dengan harapan bahwa aset tersebut akan memberikan kontribusi pendapatan bagi perusahaan secara tidak langsung dan memiliki masa manfaat lebih dari 12 bulan. Umumnya, aset tidak lancar merupakan asetaset yang memang menunjang pelaksanaan kegiatan utama perusahaan dalam memperoleh pendapatan. Aset tidak lancar terdiri dari aset berwujud (tangible asset) dan aset tidak berwujud (intangible asset).

Aset berwujud adalah aset yang memiliki wujud fisik, seperti tanah, bangunan, peralatan, kendaraan, dan lain-lain. Sedangkan aset tidak berwujud adalah aset yang tidak memiliki wujud secara fisik. Kepemilikan atas aset ini ditandai melalui penguasaan hak kepemilikan secara hukum formal. Contoh aset tidak berwujud antara lain: hak paten, hak cipta, merek dagang, hak waralaba (franchise), goodwill, dan sebagainya. Berdasarkan UndangUndang Nomor 1 Tahun 2004 tentang Perbendaharaan Negara dan Peraturan Pemerintah Nomor 6 Tahun 2006 tentang Pengelolaan Barang Milik Negara/Daerah yang telah mendapat penyempurnaan dengan Peraturan Pemerintah Nomor 38 Tahun 2008, serta Peraturan Menteri Dalam Negeri Nomor 7 Tahun 2007 tentang Pedoman Teknis Pengelolaan Barang Milik Daerah dijelaskan bahwa yang disebut sebagai barang milik negara/daerah sebagai berikut: (1) Barang milik negara/daerah meliputi: a. Barang yang dibeli atau diperoleh atas beban APBN/APBD; atau b. Barang yang berasal dari perolehan lainnya yang sah. (2) Barang sebagaimana dimaksud pada ayat (1) huruf b meliputi: a. Barang yang diperoleh dari hibah/sumbangan atau yang sejenis; b. Barang yang diperoleh sebagai pelaksanaan dari perjanjian/kontrak; c. Barang yang diperoleh sesuai dengan ketentuan peraturan perundangundangan; atau $d$. Barang yang diperoleh berdasarkan putusan pengadilan yang telah memperoleh kekuatan hukum tetap. Barang Milik Negara merupakan bagian tak terpisahkan dari Keuangan Negara. Menurut $M$ Hadi, Keuangan negara adalah semua hak dan semua kewajiban yang dapat di nilai dengan uang, demikian pula segala sesuatu baik yang berupa uang maupun barang yang dapat dijadikan milik negara, berhubungan dengan pelaksanaan hak dan kewajiban dimaksud.

\section{Larangan Penggunaan Aset Negara Di Luar Jam Kerja Atau Kegiatan Dinas}

Komisi Pemberantasan Korupsi (KPK) secara resmi melarang fasilitas mobil dinas untuk keperluan mudik, meskipun mobil dinas termasuk fasilitas yang melekat pada pejabat, namun penggunaan di luar untuk kepentingan kedinasan tidak dibenarkan. Wakil Ketua KPK Busyro Muqoddas menegaskan, menggunakan mobil dinas untuk mudik adalah hal yang tidak dibenarkan. KPK telah mengedarkan surat himbauan ke semua lembaga untuk tidak menerima atau memberikan fasilitas tertentu dalam rangka menyambut hari raya Idul Fitri dan Wakil Menteri Pendayagunaan Aparatur Negara (Wamen PAN) Eko Prasojo menyatakan, kendaraan dinas itu hanya boleh digunakan untuk kepentingan dinas tidak boleh dipakai untuk mudik ke luar kota. Menurut Eko Prasojo, penggunaan kendaraan dinas telah diatur dalam Peraturan Menteri Pendayagunaan Aparatur Negara Nomor 87 Tahun 2005 tentang Pedoman Peningkatan Pelaksanaan Efisiensi, Penghematan dan Disiplin Kerja. Dalam Peraturan itu disebutkan bahwa penggunaan kendaraan dinas dibatasi 
hanya pada hari kerja. Kendaraan dinas operasional bagi para PNS juga hanya boleh digunakan di dalam kota, penggunaan mobil dinas keluar kota harus dengan izin tertulis dari pimpinan instansi pemerintah, atau pejabat yang ditugaskan sesuai kompetensinya. Larangan ini diperkuat pernyataan Menteri Dalam Negeri (Mendagri) Gamawan Fauzi menegaskan, menggunakan mobil dinas untuk mudik merupakan penyalahgunaan wewenang. Penggunaan kendaraan dinas untuk mudik berarti melampaui kewenangan. Kepada PNS yang melanggar, dapat dikenakan sanksi disiplin oleh atasannya. Aturan itu, tertuang dalam Peraturan Pemerintah Nomor 53 Tahun 2010 tentang Disiplin Pegawai Negeri Sipil. Gamawan Fauzi mengatakan, mobil dinas tetap tidak boleh digunakan untuk mudik, meski menggunakan pelat hitam. Setiap Satuan Kerja Perangkat Daerah (SKPD) menjalankan fungsi pengawasan dan pengendalian terhadap penggunaan kendaraan dinas. Kendaraan dinas, hanya boleh digunakan untuk keperluan dinas seperti diatur dalam Peraturan Mendagri Nomor 17 Tahun 2007 tentang Pedoman Teknis Pengelolaan Barang Milik Daerah dan Peraturan Pemerintah Nomor 6 Tahun 2006 tentang Pengelolaan Barang Milik Daerah.

\section{Sanksi Yang Diterapkan Kepada Pejabat Yang Melanggar Aturan Penyalahgunaan Aset Negara Di Luar Jam Kerja}

Hukum merupakan sarana yang di dalamnya terkandung nilai-nilai atau konsepkonsep tentang keadilan, kebenaran, kemanfaatan sosial dan sebagainya. Ketika Pejabat Negara dan Pegawai Negeri dalam pelaksanaan tugas melakukan kerugian negara, maka tepat bila diterapkan instrumen Administrasi. Hal ini didasarkan bahwa Pejabat Negara atau Pegawai Negeri telah melakukan penyalagunaan wewenang (detournement de pouvoir). Bahkan melakukan kesewenang-wenangan (daad van willekeur) dalam rangka pelaksanaan tugas yang bersumber dari jabatan itu.

Konsep penyalagunaan wewenang berimplikasi pada tanggung jawab jabatan yang berkaitan dengan tanggung jawab tata usaha negara. Sementara itu, konsep melawan hukum atau melanggar hukum yang berimplikasi pada tanggung jawab pribadi sehingga berkaitan dengan tanggung jawab pidana. Menurut Philipus M. Hadjon, bahwa instrumen penegakan Hukum Administrasi Negara meliputi pengawasan dan penegakan sanksi. Pengawasan merupakan langka preventif untuk memaksakan kepatuhan, sedangkan penerapan sanksi merupakan langka represif untuk memaksakan kepatuahan. Suatu negara hukum, pengawasan terhadap tindakan pemerintah dimaksudkan agar pemerintah dalam menjalankan aktivitasnya sesuai dengan norma-norma hukum, sebagai suatu upaya preventif, dan juga dimaksudkan untuk mengembalikan pada situasi sebelum terjadinya pelanggaran normanorma hukum, sebagai suatu upaya represif. Disamping itu, yang terpenting adalah bahwa pengawasan ini diupayakan dalam rangka memberikan perlindungan hukum bagi rakyat.

Telah disebutkan bahwa sarana penegakan hukum itu disamping pengawasan adalah sanksi. Sanksi merupakan bagian penting dalam setiap peraturan perundangundangan, dalam Hukum Administrasi Negara penggunaan sanksi administrasi merupakan penerapan kewenangan pemerintahan, dimana kewenangan ini berasal dari aturan Hukum Administrasi Negara tertulis dan tidak tertulis. Sanksi dalam Hukum Administrasi Negara yaitu alat kekuasaan yang bersifat hukum publik yang dapat digunakan oleh pemerintah sebagai reaksi atas ketidakpatuhan terhadap kewajiban yang terdapat dalam norma Hukum Administrasi Negara. Pegawai Negeri Sipil yang tidak menaati 
ketentuan sebagaimana dimaksud dalam Pasal 3 dan/atau Pasal 4 Peraturan Pemerintah Nomor 53 Tahun 2010 Tentang Disiplin Pegawai Negeri Sipil dijatuhi hukuman disiplin yaitu pada Pasal 7 dengan tidak mengesampingkan ketentuan dalam peraturan perundangundangan pidana. Pasal 7 menyatakan bahwa PNS yang tidak menaati ketentuan atau yang melakukan pelangggaran disiplin dijatuhi hukuman disiplin. Hukuman disiplin tersebut terdiri dari hukuman disiplin ringan, hukuman disiplin sedang dan hukuman disiplin berat. Dalam sanksi administrasi, sasaran penerapannya ditujukan pada perbuatan, sedangkan dalam pidana ditujukan pada pelaku. Berdasarkan Pasal 82 Peraturan Pemerintah Nomor 38 Tahun 2008 tentang Pengelolaan Barang Milik Negara/Daerah dan Pasal 85 Peraturan Menteri Dalam Negeri Nomor 17 Tahun 2007 tentang Pedoman Teknis Pengelolaan Barang Milik Daerah menyatakan bahwa: (1) Setiap kerugian negara/daerah akibat kelalaian, penyalagunaan/pelanggaran hukum atas pengelolaan barang milik negara/daerah diselesaikan melalui tuntutan ganti rugi sesuai dengan peraturan perundangundangan. (2) Setiap pihak yang mengakibatkan kerugian negara/daerah sebagaimana dimaksud pada ayat (1) dapat dikenakan sanksi administrasi dan/atau sanksi pidana sesuai dengan peraturan perundang-undangan. Pengamanan dan penyelamatan terhadap barang milik daerah, perlu dilengkapi dengan ketentuan-ketentuan yang mengatur tentang sanksi terhadap pengelola, pembantu pengelola, pengguna/kuasa pengguna dan penyimpan dan/atau pengurus barang berupa Tuntutan Ganti Rugi (TGR) yang karena perbuatannya merugikan daerah. Tuntutan ganti rugi barang dikenakan terhadap Pegawai Negeri, Pegawai Perusahan Daerah dan pegawai daerah yang melakukan perbuatan melanggar hukum atau perbuatan melalaikan kewajiban atau tidak melaksanakan kewaiiban sebagaimana mestinya sesuai dengan fungsi atau status jabatannya, sehingga karena perbuatannya tersebut mengakibatkan kerugian bagi daerah. Tuntutan ganti rugi barang tidak dapat dilakukan atas dasar sangkaan atau dugaan, akan tetapi harus didasarkan pada kenyataan yang sebenarnya dan dalam pelaksanaanya tidak perlu menunggu Keputusan Pengadilan Negeri. Istilah keuangan negara dalam UndangUndang Nomor 31 Tahun 1999 tentang Tindak Pidana Korupsi jo. Undang-Undang Nomor 20 Tahun 2001 tentang Perubahan atas Undang-Undang Nomor 31 Tahun 1999 ini tercantum dalam Pasal 2 Ayat (1) yang menyatakan bahwa setiap orang yang secara melawan hukum melakukan kegiatan memperkaya diri sendiri atau orang lain atau suatu korporasi yang dapat merugikan keuangan negara atau perekonomian negara, dipidana dengan pidana penjara seumur hidup atau pidana penjara paling singkat 4 (empat) tahun dan paling lama 20 (dua puluh) tahun dan denda paling sedikit Rp. 200.000.000,00 (dua ratus juta rupiah) dan paling banyak Rp. 1000.000.000,00 (satu miliar rupiah). Pasal 3 menyatakan Bahwa setiap orang yang dengan tujuan menguntungkan diri sendiri atau orang lain atau suatu korporasi, menyalahgunakan kewenangan, kesempatan atau sarana yang ada padanya karena jabatan atau kedudukan yang dapat merugikan keuangan negara atau perekonomian negara, dipidana dengan pidana penjara seumur hidup atau pidana penjara paling singkat 1 (satu) tahun dan paling lama 20 (dua puluh) tahun dan atau denda paling sedikit Rp.50.000.000,00 (lima puluh juta rupiah) dan paling banyak $\mathrm{Rp}$. 1.000.000.000,00 (satu milyar rupiah). Ayat di atas dapat dicermati lebih lanjut, yaitu bahwa terdapat 3 (tiga) pengertian yaitu kegiatan tindak pidana korupsi, pengertian keungan negara, dan perekonomian negera. Lebih lanjut pengertian keuangan negara disebutkan dalam kegiatan penjelasan umum Undang-Undang Tindak Pidana Korupsi, 
yaitu bahwa keuangan negara adalah seluruh kekayaan negara dalam bentuk apapun yang dipisahkan atau yang tidak dipisahkan termasuk di dalamnya segala bagian kekayaan negara dan segalahak dan kewajiban yang timbul karena: 1 . Berada dalam penguasaan, perngurusan dan pertanggungjawaban pejabat lembaga negara, baik tingkat pusat maupun di daearah 2. Berada dalam penguasaan, pengurusan, dan pertanggungjawaban Badan Usaha Milik Negara/Badan Usaha Milik Daerah, yayasan, Badan Hukum, dan perusahaan yang menyatakan modal negara, atau perusahaan yang menyertakan modal pihak ketiga berdasarkan perjanjian dengan negara. Pengertian terakhir adalah tindak pidana korupsi dimana disampaikan bahwa tindak pidana korupsi adalah sebagai berikut:

1. Setiap orang yang secara melawan hukum melakukan perbuatan memperkaya diri sendiri atau orang lain atau suatu korporasi yang dapat merugikan keuangan negara atau perekonomian negara.

2. Setiap orang yang dengan tujuan menguntungkan diri sendiri atau orang lain atau suatu korporasi, menyalahgunakan kewenangan, kesempatan atau sarana yang ada padanya karena jabatan atau kedudukan yang dapat merugikan keuangan negara atau perekonomian negara. Dalam rumusan di atas pengertian melawan hukum dalam tindak pidana korupsi dapat pula mencakup perbuatanperbuatan tercela yang menurut perasaan keadilan masyarakat harus dituntut dan dipidana. Adapun yang dimaksud dengan merugikan adalah sama artinya dengan menjadi rugi atau menjadi berkurang, sehingga dengan demikian yang dimaksud dengan unsur merugikan keuangan negara adalah sama artinya dengan menjadi ruginya keuangan negara atau berkurangnya keuangan negara.

\section{PENUTUP}

Konsep penyalagunaan wewenang berimplikasi pada tanggung jawab jabatan yang berkaitan dengan tanggung jawab tata usaha negara. Sementara itu, konsep melawan hukum atau melanggar hukum yang berimplikasi pada tanggung jawab pribadi sehingga berkaitan dengan tanggung jawab pidana. Pejabat yang menggunakan aset negara/daerah untuk kepentingan pribadi atau kepentingan-kepentingan di luar fungsi jabatan dan kedinasan yang dapat mengakibatkan kerugian negara/daerah diberikan berupa sanksi administratif dan sanksi pidana, dalam sanksi administrasi, sasaran penerapannya ditujukan pada perbuatan, sedangkan dalam pidana ditujukan pada pelaku. Berdasarkan Peraturan Pemerintah Nomor 53 Tahun 2010 Tentang Disiplin Pegawai Negeri Sipil pada Pasal 7 menyatakan bahwa PNS yang tidak menaati ketentuan atau yang melakukan pelangggaran disiplin dijatuhi hukuman disiplin. Hukuman disiplin tersebut terdiri dari hukuman disiplin ringan, hukuman disiplin sedang dan hukuman disiplin berat. Undang-Undang Nomor 20 Tahun 2001 tentang tentang Pemberantasan Tindak Pidana Korupsi pada Pasal 2 Ayat (1) menyatakan bahwa setiap orang yang secara melawan hukum melakukan kegiatan memperkaya diri sendiri atau orang lain atau suatu korporasi yang dapat merugikan keuangan negara atau perekonomian negara, dipidana dengan pidana penjara seumur hidup atau pidana penjara paling singkat 4 (empat) tahun dan paling lama 20 (dua puluh) tahun dan denda paling sedikit Rp. 200.000.000,00 (dua ratus juta rupiah) dan paling banyak $\mathrm{Rp}$. 1000.000.000,00 (satu miliar rupiah). Kemudian dalam Pasal 3 Undang-Undang Nomor 20 Tahun 2001 tentang 
$\longrightarrow \longrightarrow$ Law Jurnal

Vol 1, No 2 Agustus - Desember 2020

Pemberantasan Tindak Pidana Korupsi menyatakan bahwa setiap orang yang dengan tujuan menguntungkan diri sendiri atau orang lain atau suatu korporasi, menyalahgunakan kewenangan, kesempatan atau sarana yang ada padanya karena jabatan atau kedudukan yang dapat merugikan keuangan negara atau perekonomian negara, dipidana dengan pidana penjara seumur hidup atau pidana penjara paling singkat 1 (satu) tahun dan paling lama 20 (dua puluh) tahun dan atau denda paling sedikit Rp.50.000.000,00 (lima puluh juta rupiah) dan paling banyak Rp. 1.000.000.000,00 (satu milyar rupiah).

\section{SARAN}

Saran Saat ini perlindungan aset negara masih merujuk pada UndangUndang Tindak Pidana Korupsi. Belum ada undang-undang yang menangani mengenai aset negara secara khusus. Kami mengharapkan kedepan ada undang-undang perlindungan terhadap aset negara, dengan adanya undangundang tersebut maka aset negara bisa dilindungi sehingga tidak terjadi penyimpangan-penyimpangan terhadap aset negara.

\section{DAFTAR PUSTAKA}

\section{Buku-Buku}

Abdul Rasyid Thalib, 2008, Hukum Keuangan Negara/Daerah Dan Tindak Pidana Korupsi,

\begin{tabular}{lr}
\multicolumn{1}{c}{ Lembaga } & Pengkajian \\
Pembaharuan Hukum dan & Kebijakan \\
Publik (LP2HKP), Palu. &
\end{tabular}

Adrian Sutedi, 2010, Hukum Keuangan Negara, Sinar Grafika, Jakarta.

Andie Megantara, dkk, 2008, Manajemen Perbendaharaan Pemerintahan Aplikasi di Indonesia,

LPKPAP BPPK RI. Muhammad Djafar Saidi, Hukum Keuangan Negara, PT

\section{http://ojs.umb-bungo.ac.id/index.php/RIO}

RajaGrafindo Persada, Jakarta,.

Peter Mahmud Marzuki, 2011, Penelitian Hukum, Cetakan Ketiga, Kencana Prenada Media

$$
\text { Group, Jakarta,. }
$$

Ridwan H.R, 2011. Hukum Administrasi Negara Edisi Revisi, PT RajaGrafindo Persada, Jakarta,

\section{A. Peraturan Perundang-Undangan}

Undang-Undang Dasar Negara Republik Indonesia Tahun 1945.

Undang- Undang Nomor 17 Tahun 2003 tentang Keuangan Negara, LNRI Tahun 2003 No. 47,

TLN No. 4286.

Undang-Undang Nomor 1 Tahun 2004 tentang Perbendaharaan Negara, LNRI Tahun 2004

No. 5, TLN No. 4355.

Undang-Undang Nomor 20 Tahun 2001 tentang Pemberantasan Tindak Pidana Korupsi, LNRI

Tahun 2001, No. 134 TLN No. 4150.

Undang-Undang Nomor 12 Tahun 2011 tentang Pembentukan Peraturan

PerundangUndangan, LNRI Tahun 2011 No. 82, TLN No. 5234.

\section{B. JURNAL}

Khaidir," Analisis Yuridis Pembalikan Beban Pembuktian Pada Tindak Pidana Korupsi", Rio Law

Jurnal, Vol. 1, No. 1, 2020.

Nirmala Sari, "Pengangkatan Pegawai Negeri Sipil Dalam Jabatan Struktural, Rio Law

Jurnal, Vol. 1, No. 1, 2020. 